\title{
The Study of the 5-6 Year-old Children's Appreciation the Humour at Preschool Education
}

\author{
Elif Yalçıntaş Sezgin*, Recep Hatipoğlu \\ İnegol Vocational School, Uludag University, Turkey
}

Copyright $\bigcirc 2017$ by authors, all rights reserved. Authors agree that this article remains permanently open access under the terms of the Creative Commons Attribution License 4.0 International License

\begin{abstract}
The aim of this study is to determine how the 5-6 year-old preschool children evaluate the humour through pictural analysis of their drawings about humour. The study was conducted with 52 preschoolers aged 5-6 at independent preschools attached to the Ministry of National Education. The data were collected through drawing and interview techniques. The obtained data were analysed by using the content analysis technique. The drawings by the preschoolers were found to support the Absurd Theory, the incongruity and the stages of development in humour, Bariaud's and McGhee's theories about the preschoolers and their styles of expressing the humour.
\end{abstract}

Keywords Preschoolers' Drawings, Humour, Preschool Education

\section{Introduction}

There are various definitions of humour. In the literature humour is defined as incongruity, fun laugh, joy, pleasure and good mood (8). Humorous is defined as everything which involves in all areas of life, a nonsense and absurd idea, and everything which contributes to a person's having a good time (29). An aspect of children's humour development is the way they explain pictorial humour. That is, pictorial humour takes place in the development of humour. Brown (3) stated that there are a limited number of studies bringing out the skills of children's appreciation and description of humour. Four categories helping to describe the given explanations when looked at a humorous picture were developed: Category 1 includes the situations in which humorous elements in the picture are described as comic without giving any explanations defining why they are comic. Children say explain only why they find it comic or not. Category 2 is similar to Category 1 but there is an explanation. In Category 3, children describe the Picture as comic but they do not explain what it is comic. Category is similar to Category 3 (3). Most of the studies done between 1970 and 1980 include the appreciation of humour with mental development and comprehension and they were carried out in the experimental situations in which humour was used as a smile and laughing material a sign and indicator by using graphic stimulants. Schultz (1972) used, in his/her study, pictural cards and caricatures to study the incompatibility and resolution in children's appreciation the humour (8). There are different theories of humour in literature. Especially at preschool, according to Bariaud (2) and McGhee $(20,21)$, four characteristics of pictorial humour are used to understand pictorial humour. These characteristics are classified as: a) transferring of characteristics or displacement of characteristics; b) deformity-exaggeration in size; c) abnormal behaviours or situations; and d) misfortune or misbehaviours. The Absurd and the Empowerment Theory by Loizu (12) explains the children's sense of humour. The Theory of the Absurd consists of three categories: 1) comic gestures/ attitudes/ voices/words; 2) inconvenient activities and 3) the use of inconvenient materials. McGhee (19), the pioneer of humour development, emphasizes the importance of incongruity. According to McGhee (19), incongruity underlies in every kind of humour. Incongruity, a situation which causes an unexpected situation instead of an expected coherent situation in a case by stunning, creates a tension on a person. When the person restructures this situation as humorous, the ach laughing happens, the tension decreases and the relaxation happens (27). McGhee separates the development of humour into five phases. The children at the first phase laugh at the figure at which they attach (6 month / 12/15 months). The first humour reaction of babies is seen as a result of the experience with their parents. For example, a 6-7 months-old baby can laugh at his/her mother who controls the feeder from which milk does not come by taking it in her mouth or at his/her father walking like a penguin (21). The children begin to use an abject instead of another object at the second phase (inconsistent behaviours) (12/15 months 3,4,5 years old). For example, 18 months-old Sally's laughing when she uses a toy cube as if it was a telephone and then she hangs up $(6,21)$. The children laugh by naming people, objects or body parts in a different way at the third phase (the naming of event, people in an inconsistent way) 
$(2,3,4$ years old). They find miscalling on purpose comic. For example, they can laugh by naming a cat as a dog, a hand as a foot or they become happy they show a cat as a dog, a hand as a foot, an eye as a nose. The child must notice that there is an incongruity between the real and what he/she did so that such a situation can be perceived as a humorous situation $(6$, 21).

McGhee (21) evaluates the fourth phase (conceptual incongruity) in different categories: 4a) playing with the sounds of the words: Children like playing with the sounds (not meanings) of the words at this stage. For example, they laugh by producing combinations like daddy, paddy, faddy or silly, dilly, willy, etc.; 4b) The combination of meaningless and real words: Children like combining words in an absurd way even though they know it is wrong. For example, they say "I want more potato/dirt/guitar juice, chair soup, apple shoes, butter hats, etc. $(11,21) ; 4 \mathrm{c})$ the distortion of characteristics of objects, people or animals: Children, at this stage, like adding some characteristics which do not belong to people, animals or objects, removing the present characteristics, changing the size, color, shape of the known things. They laugh at the situations, objects, and people having exaggerated characteristics and the inconsistent and impossible behaviours. For example, a person has a dog head, a cat that doesn't have a tail, a person having a square head, big ears, a skating cow (21). 4d) Giving names related to the opposite sex: Children, at this stage, laugh at naming as opposite sex. For example, telling 'This is Mary' by showing Tommy or saying 'hello Bobby' to Susie $(11,21)$.

At the fifth stage (multiple senses and the beginning of humour like the adults') (6/7 years old and later), children can understand and find funny the jokes in which there are words having several meanings thanks to their knowledge about the doubleness of the words. Rhymes are funny for children at this stage (21).

According the psychoanalytic theory, desires and fears underlie in children's drawing works. Children can express these feelings symbolically or secretly, which shows that children's mood can be understood through their drawings and their drawings can be used for this purpose. Drawings provide an advantage to observe individuals give also the opportunity to evaluate cultural and social determinants having a role in choosing topic and figure (31). Drawing is an image of the most natural imaginations of emotional and intellectual life that a child expresses in a typical and simple way. This characteristic, which is a reflection of the child's inner world and general development, shares similarities with the emotional period that important artists (painters) experience. Some drawings, symbols and signs that children obtain through perception are extremely meaningful in terms of activity period and they can be seen as important factors reflecting their world in a plain, pure and direct way (1). Children can reflect their feelings through drawings and they can express their sentiments and opinions about events. Drawings by children are accepted as a mirror of their inner worlds. Many researches have been done on his subject (5).
When the related literature is examined there are limited studies that examine how humorous situations are seen by preschool children. The children were shown certain drawings and the ways by which the children appreciated the humorous situation were examined or they were asked to take photos of the situations they find comic $(2,12,14)$. It is seen that the situations in which children appreciate humour by looking at the pictures they drawn themselves were not studied. Therefore, The aim of this study is to examine the drawings in which the preschoolers aged 5-6 express the situations at which they laugh and the situations they find funny picture analysis. In this regard, the following questions were tried to answer:

- In the children's drawings related to humour, which situations did they draw as a funny state?

- In the children's drawings related to humour, which people, objects or animals did they draw as a funny element?

- In the children's drawings related to humour, which behaviour, conduct and attitude did they draw as a funny situation?

\section{Method}

\subsection{Study Group}

To determine the study group, purposive sampling method, which is often used for qualitative research, was preferred. The participants in the study determined the purposeful sampling method. The purposeful sampling gives the opportunity of studying the situations giving abundant information in depth. The situation sampling, which is one of the purposeful sampling methods, is a sampling that provides speed and practicability for a study (35). For this reason, in this study, the convenience sample, which is one of the purposeful sampling methods, was used. A criterion to determine the children was designated from the convenience sampling. 5-6 year-old children were selected as a criterion. 5-6 year-old children are at the pre-schema period and they are eager to talk about their drawings and they are aware that they draw pictures representing their feelings and thoughts. Towards 6 years old, the proportions begin to become more realistic and the details increase. Transparent pictures, which are called as rontgen or transparent, show up. The use of colors is accidental. The details in human figures (like skirt, pants, etc.) begin to increase (31). The study group consists of 52 preschoolers (28 female, 24 male), of whom 25 preschoolers aged 5 and 27 aged 6 at Public independent preschools attached to the Ministry of National Education, in the centre of Bursa. The study was conducted with voluntary preschoolers who show normal development.

\subsection{Data Collection Means}

In this study based on qualitative research techniques, the 
semi-structured interview and expressing through drawings were combined.

\section{Semi-structured interview:}

The researcher came in the class with the class teacher and introduced herself. She stated that she would do drawing activities with them at that day. Then she interviewed with the child alone in another classroom. Every child was asked what makes him/her laugh the most and who is the funniest person for him/her? The children were encouraged to answer.

\subsection{Drawing Technique}

Drawing is a nonverbal technique for the children and teenagers who can't express himself/herself. Drawing technique is a kind of technique opening a window to children's opinions and emotions and revealing the image in the child's mind (30). In addition, the usage of drawing technique is also important in multiple fields. For example, drawings are used to gather information about the child's communication, expressing himself/herself and feelings, his/her problem solving, the problematic children's feelings and memory development (15). The quality of drawings in the picture and the content of the drawing reveal the perception of the child about himself/herself, the people around himself/herself (28). In this study, the children were interviewed by asking them questions about people or situations that make them laugh the most in order to encourage the children to draw pictures and remember them of the events which make them laugh. They were asked which event makes him/her laugh; who or what/ which animal or object makes him/her laugh and when they laugh. After the meeting, he/she was asked to draw the picture of the person, object, animal or event that makes him/her laugh. After he/she had drawn, the researcher interviewed with them face-to-face and she asked them to express their drawings and she wrote what the child said.

\subsection{Data Collection}

Each child was introduced into another room by the researcher and he/she was given a sheet of A4 paper and pastels of every color so that they can draw a picture. While the children were drawing, the researcher kept notes and the figures drawn by the children were recorded.

\subsection{Data Analysis}

The data obtained from this study were analyzed according to the content analysis approach. The researcher composed the codes and themes directly, which were not determined before, from the obtained data in conformity with the content analysis utilizing the related literature. The notes kept during the interview with every child were organized and prepared for a general coding before the content analysis. Content analysis is a general term which contains several strategies to analyze a composition (23). Content analysis is formed at the stages of obtaining data through interview, observation and documents, coding of data, finding the themes, organizing the codes and themes, defining the findings and interpreting them (35). In the study, validity and reliability were obtained by applying triangulation technique. The researcher triangulation, which is done by more than one researcher in the same research at the stages of data collection and analyses within the context of triangulation techniques (16), was applied in the study. In this context, all the researchers worked together at the stage of data collection and two researchers coded separately. The analyses realized by these two researchers were looked over with a third researcher. The analyses were completed by discussing on the different and incompatible codes. However, the obtained data were examined if they were compatible with each other and then the reliability was obtained. The analyses and the decisions related to the types of significant made by the experts were coded separately and the reliability of the research was estimated by using the formula Reliability $=$ Consensus/Consensus + Disagreement $\mathrm{x} 100$ (17). 


\section{Findings}

Table 1. In children's drawings, the humour signs in the situations they found funny (N: 52)

\begin{tabular}{|c|c|c|c|}
\hline Drawn Items & Female & Male & Total \\
\hline \multicolumn{4}{|l|}{ Family } \\
\hline Mother & 7 & 1 & 8 \\
\hline Father & 2 & 5 & 7 \\
\hline Elder sister/brother & 6 & 4 & 10 \\
\hline Sister/brother & - & 1 & 1 \\
\hline \multicolumn{4}{|l|}{ Other people } \\
\hline Friend & 5 & 4 & 9 \\
\hline Teacher & - & 1 & 1 \\
\hline Foreigner & 2 & 1 & 3 \\
\hline Dwarf & - & 2 & 2 \\
\hline \multicolumn{4}{|l|}{ Manimal } \\
\hline Horse - Human & 1 & - & 1 \\
\hline Sheep - Human & - & 1 & 1 \\
\hline Fish - Human & - & 1 & 1 \\
\hline Millipede Human & - & 1 & 1 \\
\hline Donkey-Human & - & 1 & 1 \\
\hline \multicolumn{4}{|l|}{ Animal } \\
\hline Horse & 1 & 1 & 2 \\
\hline Bear & - & 1 & 1 \\
\hline \multicolumn{4}{|l|}{ Items belonging to nature } \\
\hline Sun & 1 & 1 & 2 \\
\hline Tree & - & 2 & 2 \\
\hline Cloud & 1 & 2 & 3 \\
\hline Flower & 1 & 1 & 2 \\
\hline Star & 1 & - & 1 \\
\hline \multicolumn{4}{|l|}{ Entertainment hero/story hero/ imaginary hero } \\
\hline Clown & 2 & 3 & 5 \\
\hline Acrobat & - & 1 & 1 \\
\hline \multicolumn{4}{|l|}{ Objects } \\
\hline Socks & - & 1 & 1 \\
\hline Hat & 1 & - & 1 \\
\hline Clown nose & 1 & - & 1 \\
\hline TV & 1 & - & 1 \\
\hline Cornet & 1 & - & 1 \\
\hline Unicycle & - & 1 & 1 \\
\hline Hairpin/Crown & 1 & - & 1 \\
\hline Shoes & 1 & - & 1 \\
\hline House & - & 1 & 1 \\
\hline Car & - & 2 & 2 \\
\hline Distorting mirror & - & 1 & 1 \\
\hline Hat & 1 & - & 1 \\
\hline Shirt & 1 & - & 1 \\
\hline Photo & 1 & - & 1 \\
\hline Balloon & 1 & - & 1 \\
\hline
\end{tabular}

*Since the child used more than one item, the general total is more than the total number of children. 
Table 2. General categories of drawings by children in terms of humour

\begin{tabular}{|l|l|}
\hline Category & \multicolumn{1}{c|}{ Definition } \\
\hline \multirow{5}{*}{ Incongruity } & $\begin{array}{l}\text { Humorous gestures : People using humorous gestures Incongruous/strange behavours (animals/people): the drawings related to } \\
\text { people or animals behaving in an incongruous way Objects, distorsion (corrupting/transfert) of the characteristics of people or } \\
\text { animals: They laugh at the situations, objects or people having exaggerated characteristics or incongruous or impossible behaviours. } \\
\text { For example, a person having a dog head, a cat that does not have a tail, a person with a square head, big ears, a skating cow... A cow } \\
\text { wearing a hat or a man having dog ears can been example }(2,21) .\end{array}$ \\
\cline { 2 - 3 } & $\begin{array}{l}\text { Incongruous appearance: children find funny the pictures of people, animals or objects having incongruous coulour, size or shape. } \\
\text { The naming of objects, events and people in an incongruous way: Children like naming the objects, people and events in a different } \\
\text { way. They find funny to name inaccurately on purpose (21). }\end{array}$ \\
\cline { 2 - 3 } & $\begin{array}{l}\text { Naming inaccurately: Children name an object or a person inaccurately and they find it funny at this stage (for example, telling ear } \\
\text { instead of nose) (21) }\end{array}$ \\
\cline { 2 - 3 } & $\begin{array}{l}\text { Misfortunes/clumsiness or misbehaviours: Children laugh at clumsinesses or misfortunes by people or animals and they find them } \\
\text { funny. For example, the fact a cat spills milk while it is trying to reach it or that a fish ejects water while a man is looking at a fish.... } \\
(2,21)\end{array}$ \\
\hline
\end{tabular}

At the table 1, it was seen that the majority of the children preferred to draw, as person, elder brother/sister $(\mathrm{f}=10)$, friend $(\mathrm{f}=9)$ and mother $(\mathrm{f}=8)$ when they were asked to draw at which they laugh. However, the most preferred person to draw was father $(\mathrm{f}=7)$ after mother. They drew clown $(\mathrm{f}=5)$ as entertainment hero.

The drawings by the children related to humour were categorized below according to Bariaud (2), Loizou $(12,14)$ and McGhee $(20,21)$.

The obtained findings and categories as well as the interview with the children and their drawings were indicated below.

Incongruity: Humorous gestures: Gestures such as laughing, smiling, sticking out his/her tongue, and other facial expressions (for example, sticking out his/her tongue, tweaking cheeks, etc.) are humorous signs. Below are examples related to the children's humour category:

The researcher: What did you draw?

$C$ 26: My mother and my elder sister.

The researcher: Why is this drawing funny according to you?

C 26: My mother and my sister are raising their eyes and they do imitation like a cross-eyed(Figure1)

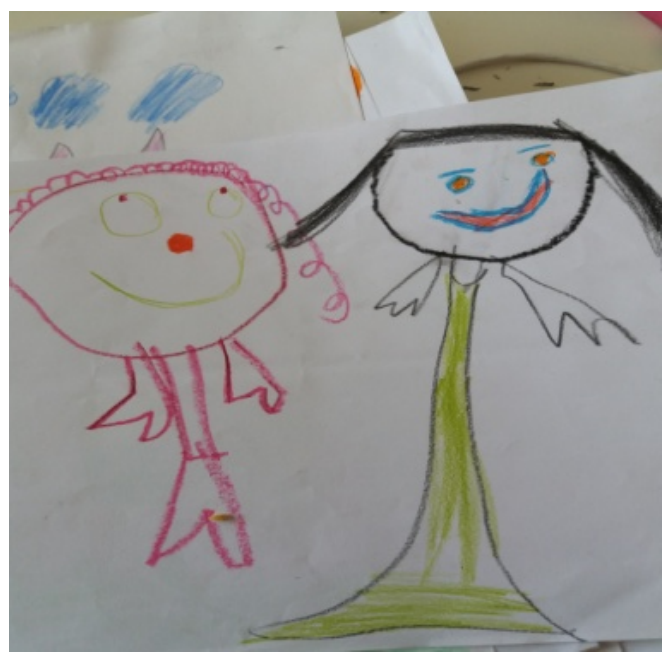

The researcher: What did you draw?

C 50: My elder brother.

The researcher: Why is this drawing funny according to you?

C 50: My brother is sticking out his tongue.

The researcher: What did you draw?

$C$ 44: My elder brother.

The researcher: Why is this drawing funny according to you?

C 44: My brother is pulling his ears and sticking out his tongue.

\section{The incongruous behaviours of animals:}

The researcher: What did you draw?

$C$ 30: A bear climbing the tree.

The researcher: Why is this drawing funny according to you?

C 30: The breech of the bear is seen while it is climbing the tree.

Transferring/giving the human characteristics to animals:

The researcher: What did you draw?

C 4: A horse.

The researcher: Why is this drawing funny according to you?

C 4: The horse is speaking like a man.

The researcher: What did you draw?

C 2: A Child having donkey ear and tail

The researcher: Why is this drawing funny according to you?

C 2: He looks like a donkey but his face is like a man's.

The researcher: So why is this drawing funny?

C 2: because he has two donkeys ear and tail (Figure 2)

The researcher: What did you draw?

C 30: A lamb and a sheep.

The researcher: Why is this drawing funny according to you?

C 30: Their faces look like a man's. They look like a man.

Figure 1. Mother and sister 


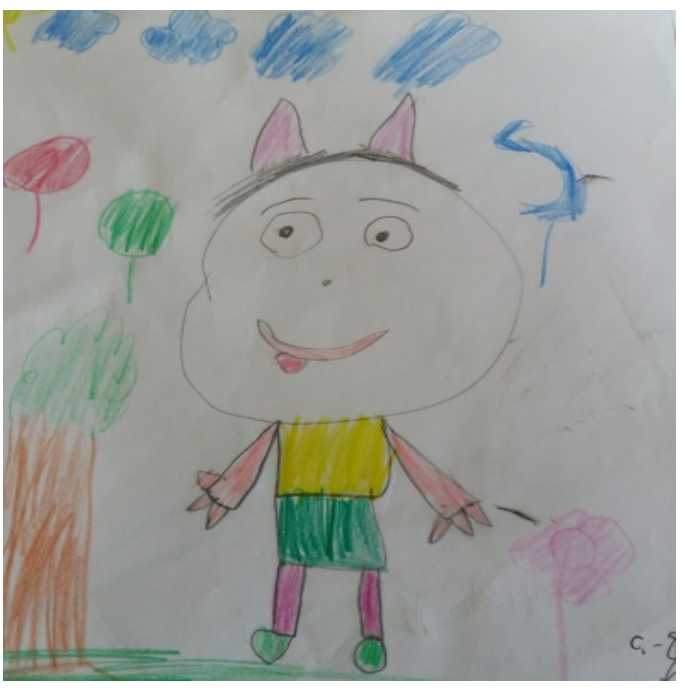

Figure 2. Child with donkey ear and tail

Incongruous behaviours of people: Children find the incongruous behaviours of people funny. Here are some examples: The fact that his/her mother wears socks on her hands, that his/her father wears his shirt inside out, that his/her father wears a clown nose, that his/her elder brother or sister cocks a snook, that his/her elder sister does imitation like a monkey, that his/her brother raises his/her hands and makes a strange noise, that his/her father plays the halay at home, different gestures of the teacher, a man mounting a horse backwards, a man doing acrobatics on a cycle, the fact that his/her mother's using shoes like a telephone, the fact that his/her elder sister sucks a nipple...

Some examples were given below:

The researcher: What did you draw?

C 56: My mother's shoes.

The researcher: Why is this drawing funny according to you?

C 56: While my mother plays house with me, she uses shoes like a telephone.

The researcher: What did you draw?

C 51: A man riding a horse.

The researcher: Why is this drawing funny according to you?

C 51: Because the man mounted a horse backwards and he, as if he went back

\section{Incongruous appearance:}

The researcher: What did you draw?

C 20: My father and my elder brother.

The researcher: Why is this drawing funny according to you?

C 20: My elder brother and father look small while they are coming.

The researcher: What did you draw?

C 17: My elder brother, myself, socks with child figures.

The researcher: Why is this drawing funny according to you?

C 17: Because my elder brother wears socks with child figures. (Figure 3)

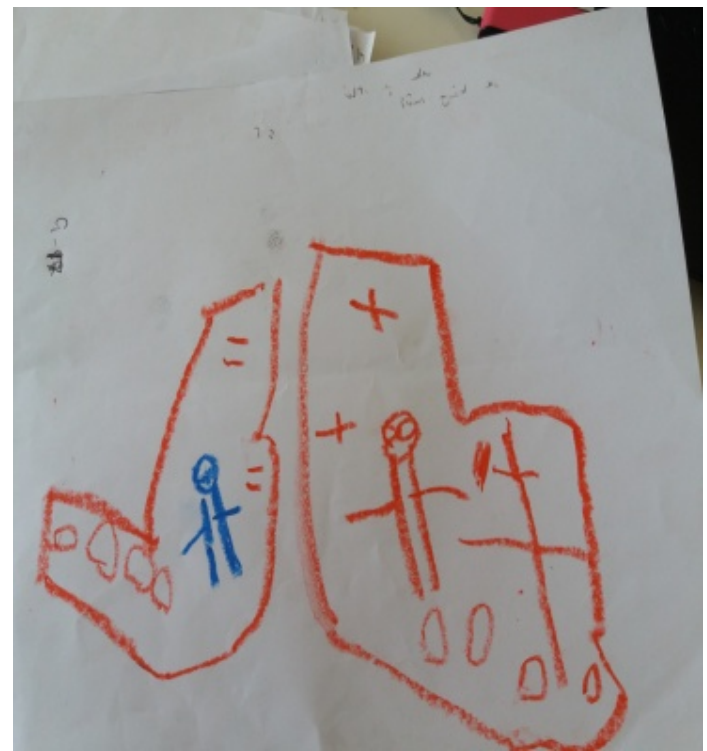

Figure 3. Socks with child

The researcher: What did you draw?

$C$ 22: Myself, my mother, my father, distorting mirror.

The researcher: Why is this drawing funny according to you?

C 22: Because we look different (funny) in front of the mirror.

The researcher: What did you draw?

C 52: I drew my mother and father's wedding photo.

The researcher: Why is this drawing funny according to you?

C 52: My father's wedding suit is comic.

The researcher: Why is it comic?

C 52: his hat is comic (A family from Azerbaijan) (Figure 4)

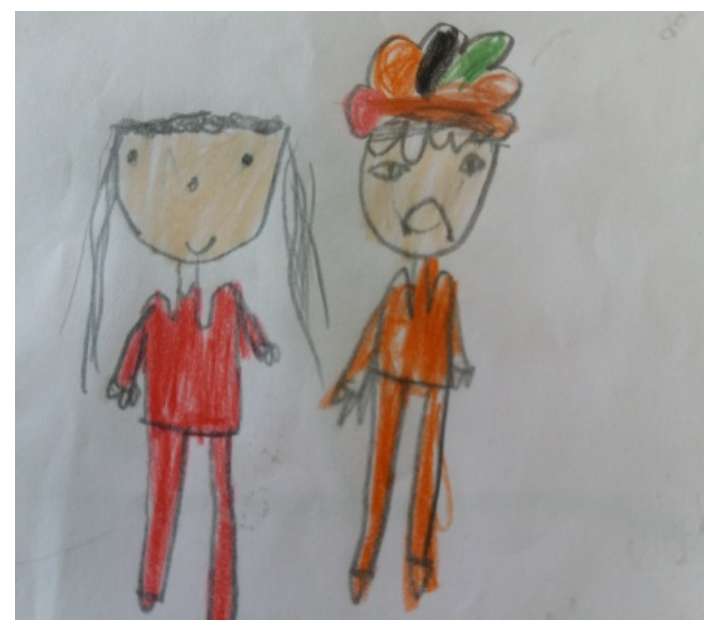

Figure 4. Mother and father's wedding photo

The researcher: What did you draw?

C 49: My friend wearing a hairclip like a crown, flower, star, cloud, sun.

The researcher: Why is this drawing funny according to 
you?

C 49: Because my friend's crown is too big, moreover it bigger than her head (Figure 5)

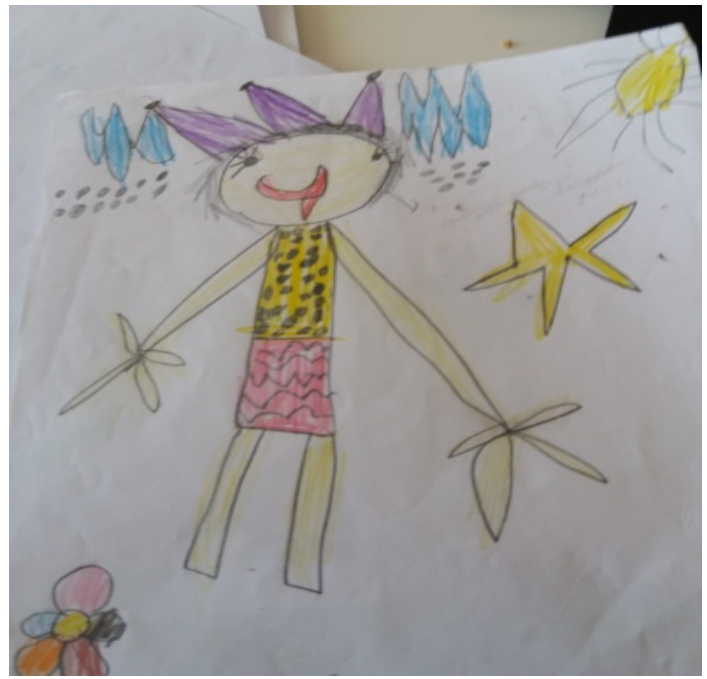

Figure 5. Friend

The researcher: What did you draw?

C 35: A dwarf.

The researcher: Why is this drawing funny according to you?

C 35: The dwarfs walking on the road make me laugh a lot.

The researcher: Why is it funny?

$C$ 35: They are adults but they look like a child.

The researcher: What did you draw?

C 20: A dwarf.

The researcher: Why is this drawing funny according to you?

C 20: The fact that the dwarf's dancing makes me laugh.

The naming of objects, events and people in an incongruous way and the naming inaccurately:

The researcher: What did you draw?

C 6: My friend and I are talking.

The researcher: Why is this drawing funny according to you?

C 6: He/she calls me inaccurately and I'm laughing at it a lot.

The researcher: What did you draw?

C 9: My mother.

The researcher: Why is this drawing funny according to you?

C 9: Because my mother sings

The researcher: Why is it funny?

$C$ 9: She sings in a wrong way.

The researcher: What did you draw?

C 11: My mother.

The researcher: Why is this drawing funny according to you?

C 11: While she is talking to me, she calls me Çiçek, so I laugh at it a lot.
Misfortunes or misbehaviours: Another situation at which children laugh a lot is clumsinesses or misbehaviours that people or animals do. In the study, children stated, through drawings and verbally, that they find their elder brother's or friend's falling, the clown's dropping the balls funny. Here are some examples:

The researcher: What did you draw?

$C 4$ : The clown is playing with the balls.

The researcher: Why is this drawing funny according to you?

C 4: The clown is dropping the balls on the floor. Isn't is funny? (Figure 6)

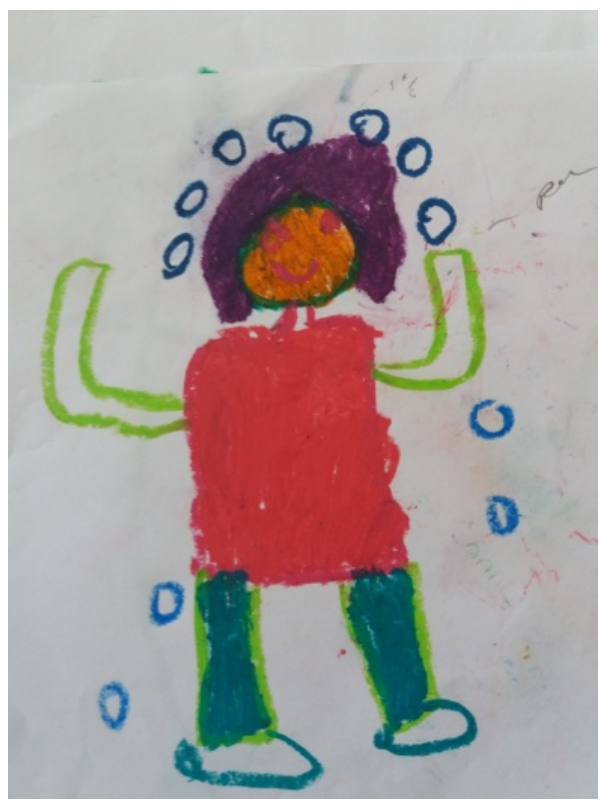

Figure 6. Clown

The researcher: What did you draw?

C 28: child (girl), ice cream cone, ice cream

The researcher: Why is this drawing funny according to you?

C 28: Dropped the ice cream from the cone (Figure 7 )

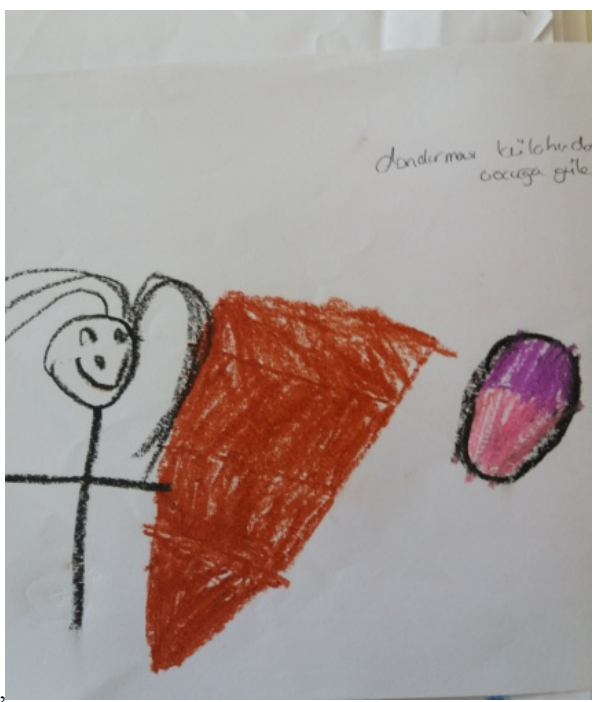

Figure 7. İce cream 
Table 3. Below are the numbers of drawings according to the categories of humour in the drawings of children.

\begin{tabular}{|c|c|}
\hline Topics Number of drawings & \\
\hline Humorous gestures & 10 \\
\hline Incongruous behaviours & 1 \\
\hline Animal & 16 \\
\hline People & 5 \\
\hline Giving human characteristics to animals & 9 \\
\hline Incongruous appearance: colour, shape, size & 4 \\
\hline $\begin{array}{c}\text { Naming of objects, events and people in an } \\
\text { incongruous way/Naming inaccurately }\end{array}$ & 7 \\
\hline Misfortunes or misbehaviours & 52 \\
\hline TOTAL & \\
\hline
\end{tabular}

\section{Conclusions and Discussion}

The results of this study were discussed under two headings: the concept of humour in the drawings by children in terms of drawing technique and the Absurd theoryincongruity.

Drawing technique and incongruity:

5-6 year old children are at the period of the developments stages. The preschematic period (4-7 years old) are the period at which children begin to use symbolic systems. At this stage, children use symbols reflecting certain characteristics about the real world and reflect the similar ones of the objects he/she saw and knew through materials belonging to drawing plane $(9,22)$. Even though children use symbols belonging to the real world to draw humorous situations, asking them questions about their drawings are important in order to obtain the validity and reliability of the study. In this study, even though the interviews were before the drawing activities, they were asked questions by the researcher about their drawings after they completed them and their responses were recorded. Thus, the humorous situations drawn by the children became more explicative.

According the findings of the study, it was seen that the children preferred mostly elder brother/sister as person to draw in the situations they find funny. Then friend, mother and finally father were mostly preferred. They preferred clown as an entertainment person. In the drawings related to elder brother/sister, the situations about incongruity and clumsiness were reflected. In the drawings related to friend, the expressed humorous gestured were clumsiness, misfortune, naming of objects, events and people an incongruous or inaccurate way. Mother was expressed mostly by her using humorous gestures, naming of objects, events and people an incongruous or inaccurate way and incongruous gestures. Father was expressed mostly by incongruity, misfortune, humorous gestures and incongruous appearance. Clown was mostly expressed by misfortune, clumsiness, incongruous appearance categories.

It can be clearly seen, in the drawings by the children, that there are traces of humorous gestures and incongruous behaviours taking place in the categories of the Absurdity theory (12). In the drawings by the children, there are sticking out his/her tongue, different facial gestures, sticking out his/her tongue by pulling his/her cheeks towards both sides.

As for incongruous gestures, they drew and expressed mostly, as humorous gestures, the incongruous gestures and behaviours of their family members (mother, father, elder brother/sister); for example, his/her elder sister's mimic of monkey, his/her father's playing halay at home).

When we talk about the distortion of the objects, people or animals, it can be seen that the children drew the transferring of human characteristics to animals (drawing human face on lamb or sheep, drawing a half human half fish picture, speaking of a horse, etc.); here, visual humorous is the transferring of a characteristic belonging to a category to another category. A cow wearing a hat or a man having dog ears is good example for this. Preschoolers find funny the transferring of human characteristics to animals in their drawings and expressing of humorous situation $(2,13,21)$.

When we examine the drawings by the children according to the incongruous appearance category, it can be seen that dwarf, their images in front of distorting mirrors, the reduced appearance of his/her father and elder brother crossing the road, his/her friend's wearing an exaggerated hairpin reflect an humorous situation. Children also find the appearance of abnormal object or people (14). In the Loizou's study (14), the photos about humorous situation taken by the children were analyzed. In the photos taken by children, it was seen that they found funny the whiteness of his/her grandmother's hair, baby dolls with long legs. Another important situation that children find funny is the naming in incorrect way (for example, calling collar instead of head...). Children like naming objects, people and events in a different way. They laugh at naming people, objects and body parts in a different way. They fing comic to name incorrectly on purpose. For example, they laugh by telling $d o g$ instead of cat, socks instead of shoes $(6,21)$. In the study, it is seen, in the drawings by the children, that his/her mother's calling him/her by a false name, his/her mother's singing incorrectly, his/her friend's calling him/her by a false name are humorous situations.

Misfortunes or misbehaviours: Another situation at which children laugh is misfortune or misbehaviours people or animals make. For example, a cat's spilling milk while it tries to reach it, the ejecting of water by a fish at the man looking at it... (2,21). In the study, the fact the clown' dropping the balls, his/her friend's causing to fall him/her by holding his/her leg, etc. are called humorous situations by the children.

In the study, it was seen that the children drew pictures compatible with the humorous and incongruous development stages of the Absurdity theory (12) and the four characteristics of Bariaud (2) and McGhee's (20,21) preschooler's pictorial humour (transfer or displacement of characteristics, distortion or exaggeration of the size, 
abnormal behaviours or situations, misfortunes or misbehaviours). Similarly, in the study by Loizou (14), it was seen that the photos taken by the children were compatible with the incongruity category. The expressions of humour by the children and their understanding the photos were examined from different points of view. In these studies, even though the researchers worked on the understanding the joke, the humorous pictures and the comedies a lot $(18,3,25$ $32 ; 13)$, researches on linguistic humour are little. In this study, the children were asked to draw the situations that they find funny. Drawing is one of the ways to express themselves cosily for children (26). It was difficult to find a satisfactory study on linguistic humour since children express humorous situations through drawing. It was understood the humorous situations only by asking them questions about their drawing through face-to-face interviews and it was seen that his/her mother's calling him/her by a false name, his/her mother's singing inaccurately, his/her friend's calling him/her by a false name were called humorous situations. At the third stage (naming the objects, people or events in an incongruous way $-2-3-4$ years old), children like naming the objects, events or people in an incongruous way. They laugh by naming the objects, events or body parts in a different way). They find comic to nickname on purpose. For example, telling dog instead of cat, socks instead of shoes, etc. $(6,21)$. This category belongs to incongruity category.

When the literature was examined, it is seen that there are a few studies about pictural humour at preschool period. A similar study was carried out by Pitri (36) 578 children (between 4,5-12 year-old) participated in this study which was conducted to find out better the children's untutored graphical presentations as a form of visual development rather than a form of perceptive development. The children were asked to draw something comic and to explain them. The aim of the study is to determine the themes of children's humour art. It was found out that there were different categories and characters of humorous art among children and there were not differences in children's humorous images according to their genders. Similarly, Loizou asked six children (5-6 year-old) to take pictures of the things they find comic at home and at school by using a portable camera to study children's appreciation and perception skill of humorous situations in 2011. He analyzed the pictures taken by children in the context of the theory of the absurd and empowerment. He explained the humorous elements according to the absurd and empowerment theory. Pushe-Navarro (24), in his study, two experiments were done to examine pictorial humour as an unusual but legitimate way to approach the study of children's representational activity and the transition from implicit to explicit knowledge. In both experiments, the participants were 3-4 year-old children. In the experiment 1 , he studied the understanding of two pictorial jokes using two conditions, choice and verbal production. In the experiment 2 , he compared the results of the experiment 1 with the comprehension that children had two versions of three pictorial jokes presented in two different sessions. The results showed three levels of comprehension. Changes according to the level were analyzed. The data suggest a tendency to stay at the same level although a few children descended or ascended. These changes occur within a short period of time and provide support for a particular conceptualization of cognitive development. Implications for illustrated mechanisms of change and representational redescriptions in young children were discussed. Loizou, in his study in (13), he showed comic drawings including multiple inconsistency to 80 preschoolers and examined the responses and reactions about the drawings. Both male and female preschoolers could explain equally the inconsistencies and comic parts in the drawings. Guo, Zhang, Wang and Xeromeritou (8) examined, in their study conducted with Chinese and Greek children of 4,5 - 5,5 year-old, the relation between humour and cognitive development. The drawings including humorous elements were shown to the children and they were asked to determine and explain the inconsistencies in the pictures. It was seen that there was a significant and positive relationship with both Chinese and Greek children's describing humour and their cognitive development.

In this study, it was aimed at children's expressing humorous situation. It was seen that the study supports the Absurdity theory (12), the humorous development stages of the preschoolers, and Bariaud's (2) and McGhee's (20, 21) understanding of pictorial humour by preschoolers.

This study was conducted to understand children's perception of humour. In the following studies, it can be done studies on younger children and on how they make their friends, parents and elder brothers/sisters laugh. In order to increase data diversity in the studies on children, drawings by children, interviews with children and photos taken by children can be used.

\section{REFERENCES}

[1] ARTUT, Ö. G. K. Okul öncesi resim eğitiminde çocukların çizgisel gelişim düzeylerine ilişkin bir inceleme. Çukurova Üniversitesi Sosyal Bilimler Enstitüsü Dergisi, 13(1),2004

[2] Bariaud, F.Age differences in children's humour. Journal of Children in Contemporary Society.20, 15-45.1989

[3] Brown, I. Young children's explanations of pictoral humor: a preliminary study. Early Child Development and Care, 93(1), 35-40,1993

[4] Catte, M., \& Cox, M. V.Emotional indicators in children's human figure drawings. European Child \& Adolescent Psychiatry, 8(2), 86-91, 1999.

[5] Doğru, S. S. Y., Turcan, A. İ., Arslan, E., \& Doğru, S. Çocukların Resimlerindeki Aileyi Tanılama Durumlarının Değerlendirilmesi. Selçuk Üniversitesi Sosyal Bilimler Enstitüsü Dergisi, (15), 223-235,2006 
[6] Gander, M. J., \& Gardiner, H. W. Çocuk ve ergen gelisimi.(6. Baski). Pmge Kitabevi, Ankara, 2007

[7] Gross, J., \& Hayne, H. Drawing facilitates children's verbal reports of emotionally laden events. Journal of experimental psychology: applied, 4(2), 163,1998

[8] Guo, J. , Zhang, X., Wang, Y. ve Xeromeritou, A. Humour among Chinese and Grek preschool children in relation to cognitive development. International Electronic Journal of Elementary Education, 3(3),153-170, 2011

[9] Gürtuna, S. Güzel Sanatlar Eğitiminde Yeni Değerler. Hasan Âli Yücel Eğitim Fakültesi Dergisi, 1(1), 2004

[10] Karasar, N. Bilimsel araştırma yöntemi: kavramlar, ilkeler, teknikler. Nobel Yayın Dağıtım, 2009

[11] Kustermann,P. Developmental Stages of Humor in Children

[12] http://www.rotenasen.de/files/wissenschaft/Humor_dev_Chil dren-(english).pd, 2003

[13] Loizou, E. Infant humour: The theory of the absurd and the empowerment. International Journal of Early Years Education, 13(1), 43-53, 2005

[14] Loizou, E. Young children's explanation of pitorial humor. Early Childhood Education Journal, 33(6), 425-431, 2006.

[15] Loizou, E .Disposable cameras, humor and children's abilities. Contemporary Issues in Early Childhood 12(2). 148-162, 2011

[16] Malchiodi, C. A. Understanding children's drawings. Guilford Press, 1998

[17] Merriam, S. B. Nitel araştırmalarda geçerlik, güvenirlik ve etik. (Çev. E. Dinç). Turan, S. (Çev. Ed.). Nitel araştırma - desen ve uygulama için bir rehber. (s.199-228). Ankara: Nobel Akademik Yayıncılık, 2013

[18] Miles, M. B., \& Huberman, A. M. Nitel veri analizi. (Sadegül Akbaba Altun \& Ali Ersoy, Çev. Ed.). Ankara: Pegem, 2015

[19] McGhee, P. E. Ü. Children's appreciation of humor: A test of the cognitive congruency principle. Child Development, 420 426, 1976

[20] McGhee, P. E. Humour: Its origin and development. San Francisco: W. H. Freeman, 1979

[21] McGhee, P. E. Play, incongruity, and humour. In T. D. Yawkey \& A. D. Pellegrini (Eds.), Child's play: Developmental and applied (pp. 219-236). Mahwah, NJ: Lawrence Erlbaum Associates, 1984.

[22] McGhee, P. E. Head, shoulders, knees and ...peanut butter. What makes young children laugh. On 2017 Retrieved from http://www.laughterremedy.com/articles/child makes laugh.html, 2017

[23] Metin, Ş., \& Aral, N. Dört-Yedđ Yaş Çocuklarının Resđm Gelđșđm Özellđklerđnđn İncelenmesđ1 The Study On
Drawing Development Characters Of The Children Between E1ghteen Month And Forty Months Old. On 2017 Retrieved from https://www.researchgate.net, 2012

[24] Powers B, Knapp T. Dictionary of Nursing Theory and Research (3rd edn). New York: Springer Publishing Company, 2006.

[25] Puche-Navarro, R. E. B. E. C. A. Graphic jokes and children's mind: An unusual way to approach children's representational activity. Scandinavian journal of psychology, 45(4), 343-355, 2004

[26] Robin, L., Keegan, J., \& Ward, K. In-depth Interview. Qualitative research practice: A guide for social science students and researchers. San Francisco: Sage Publication, 2003.

[27] Saban, A. Öğretmen Adaylarının Öğrenci Kavramına İlişkin Sahip Olduğu Metaforlar. Türk Eğitim Bilimleri Dergisi. 7 (2). 281-326, 2009.(çıkarılcak yine control et başka yerde kullanılmış mı diye)

[28] Sauthom, M. Humor development: An important cognitive and social skill in the growing child. Physical and Occupational Therapy in Pediatrics, 25(1/2), 105-116, 2005.

[29] Sayıl, M. Çocuk çizimlerinin klinik amaçlı kullanımı üzerine bir değerlendirme. Türk Psikoloji Yazılarl, 7(14), 1-13, 2004.

[30] Toraman, S. Ö. Bilim sanat merkezlerine devam eden ve etmeyen ilköğretim 12 yaş çocuklarının saldırganlık, atılganlık, çekingenlik ve mizah özelliklerinin çeşitli değişkenler açısından incelenmesi. Yayımlanmamıs yüksek lisans tezi, Gazi Üniversitesi, Ankara, 2009.

[31] Thomas, G. V., \& Silk, A. M. An introduction to the psychology of children's drawings. New York University Press, 1990.

[32] Yavuzer, H. Images of children. (12th Printing). 184 p., İstanbul: Remzi Kitabevi, 2007.

[33] Yannicopoulou, A. Visual aspects of written texts: preschoolers view comics. L1-Educational Studies in Language and Literature, 4(2), 169-181, 2004.

[34] Yaral1, K. T., Özkan, H. K., \& Aytar, A. G. Yedi Ve On Yaş Çocuklarının Sevgiyi İfade Ediş Biçimlerinin Çizdikleri Resimlere Yansıması. Kastamonu Ĕğitim Dergisi, 24(5), 2181, 2016

[35] Yüksel, M. Y., Canel, N., MUTLU, N., YILMAZ, S., \& Elif, Ç. A. P. Okul öncesi çağdaki çocukların iyi ve kötü kavram algılarının resim analizi yöntemiyle incelenmesi. Değerler Eğitimi Dergisi, 13(29), 271-303, 2015

[36] Yıldırım, A. \& Şimşek, H. Sosyal Bilimlerde Nitel Araştırma Yöntemleri, Ankara: Seçkin Yayıncılık.9.Basım, 2013

[37] Pitri, E. Children's funny art and the form it can take over time. International Journal of Education through Art, 7(1), 81-96, 2011. 